\title{
The identification of genes from the oyster Crassostrea gigas that are differentially expressed in progeny exhibiting opposed susceptibility to summer mortality
}

\author{
Arnaud Huvet ${ }^{\mathrm{a}^{\star}}$, Amaury Herpin $^{\mathrm{b}}$, Lionel Dégremont ${ }^{\mathrm{c}}$, Yannick Labreuche ${ }^{\mathrm{a}}$, Jean-François Samain ${ }^{\mathrm{a}}$ \\ and Charles Cunningham ${ }^{\mathrm{b}}$
}

\author{
a Unité Mixte de Recherche Physiologie et Ecophysiologie des Mollusques Marins, Ifremer, Centre de \\ Brest, B.P. 70, 29280 Plouzané, France \\ ${ }^{\mathrm{b}}$ Sars International Centre for Molecular Marine Biology, High Technology Centre, Thormøhlensgt.55, \\ N-5008 Bergen, Norway \\ ${ }^{c}$ Laboratoire Ifremer de Génétique et Pathologie, 17390 La Tremblade, France \\ * ahuvet@ifremer.fr Tel.: +332 982246 93; fax: +332 98224653
}

\begin{abstract}
Summer mortality associated with juveniles of the oyster Crassostrea gigas is probably the result of a complex interaction between the host, pathogens and environmental factors. Genetic variability in the host appears to be a major determinant in its sensitivity to summer mortality. Previously, divergent selection criteria based on summer survival have been applied to produce oyster families with resistant and susceptible progeny. In this paper, we describe the use of suppression subtractive hybridization to generate $150 \mathrm{C}$. gigas clones that were differentially regulated between resistant and susceptible F2 progeny. The nucleotide sequence of these clones was determined. In $28 \%$, the inferred amino sequence was found to match the products of known genes, $14 \%$ matched hypothetical proteins and a further $14 \%$ appeared to contain open reading frames (ORFs) whose product had no obvious homologue in the nucleotide databases. It has been hypothesized that differences exist in the level of energy generation and immune function between resistant and susceptible progeny. In light of this, clones encoding homologues of cavortin, cyclophilin, isocitrate dehydrogenase, sodium glucose cotransporter, fatty acid binding protein, ATPase $\mathrm{H}+$ transporting lysosomal protein, precerebellin, and scavenger receptor were analyzed by real-time PCR. These transcripts were induced in resistant progeny when compared to their susceptible counterparts. A bacterial challenge of oysters resulted in the suppression of six of these transcripts in only those that were resistant to summer mortality. This study has identified potential candidates for further investigation into the functional basis of resistance and susceptibility to summer mortality.
\end{abstract}

Keywords: Bacterial challenge; Bivalves; Differentially regulated genes; Oysters; Suppression subtractive hybridization 


\section{Introduction}

Under intensive or extensive aquaculture conditions, marine species are exposed to various stressors that can lead to an overall reduction in performance (growth, reproduction) and increased susceptibility to disease (Pickering, 1992). Significant mortality has been reported in the Pacific cupped oyster Crassostrea gigas for many years (Cheney et al., 2000) and is a major concern of oyster farmers (Goulletquer et al., 1998). Summer mortality is especially problematic in juveniles and is associated mainly with high temperatures and the oyster reproductive period. Though two oyster pathogens, Herpes like virus (Renault et al., 1994) and Vibrio spp (Lacoste et al., 2001; Le Roux et al., 2002), have been reported previously, neither was associated systematically with summer mortality. Indeed, summer mortality may well be the result of complex interactions between the host, one or more pathogens and numerous environmental factors.

Increasing the tolerance of animals of economic importance to stress and diseases by selective breeding has long been considered as feasible (Satterlee and Johnson, 1988). For oyster, genetic variability is suspected to be a major determinant in sensitivity to summer mortality (Hershberger et al., 1984) and in bivalve defence mechanisms. Within the recently established French national multidisciplinary program "Morest”, which was set-up to study the causes of summer mortality in C. gigas juveniles, divergent selection criteria were applied (Dégremont et al., 2003). A strong genetic basis for survival was observed and F2 oyster progeny were separated into two groups; resistant (R) and susceptible (S), depending on their summer survival rates (Dégremont et al., 2003). In the present study, an analysis of the molecular events underpinning the physiological differences between the R and S progeny was undertaken using suppression subtractive hybridization (SSH), a PCR-based technique that allows the identification of genes that are differentially expressed in response to stimuli. This technique combines normalization and subtraction, allowing the suppression of abundant 
transcripts while rare transcripts are enriched to the same order of magnitude (Diatchenko et al., 1996). This approach is currently used to identify genes implicated in molecular mechanisms involved in cancer, immunity and development (Bayne et al., 2001; Hofsaess and Kapfhammer, 2003). Until now, only a few transcripts encoded by genes that may be involved in oyster stress or immune responses have been reported (Jenny et al., 2002; Gueguen et al., 2003; Boutet et al., 2004).

This project was designed to compare the differential expression of C. gigas genes between $\mathrm{R}$ and S progeny during a summer mortality event that had affected only the S progeny. One hundred and fifty clones were partially sequenced and those putatively implicated in immunity or energy metabolism, systems suspected to be implicated in summer mortality, identified. The nucleotide sequence of these clones was extended and their differential expression in $\mathrm{R}$ and $\mathrm{S}$ samples analysed. The expression of these transcripts was also measured in two-year-old R and S progeny before and after a bacterial challenge to asses their value in determining susceptibility to summer mortality.

\section{Material and Methods}

\subsection{Biological material}

F2 oyster progeny were bred during March 2002 at the Ifremer hatchery in La Tremblade (France) according to divergent selection criteria and based on results of in situ survival of F1 bi-parental families (Dégremont et al., 2003). These oysters were then cultured at the Ifremer station in Bouin (France). For SSH experiments, progeny from $3 \mathrm{R}$ and $3 \mathrm{~S}$ families were placed in the same experimental raceway (April 2002) in seawater filtered to $20 \mu \mathrm{m}$ and fed $10^{9}$ Skeletonema costatum day ${ }^{-1}$ oyster $^{-1}$. When the first oysters died in the raceway (July 2002), 10 individuals were collected from each family and their mantle-gonad immediately dissected and stored in liquid nitrogen. No oysters were collected that were clearly dying. 
Frozen samples were crushed to a fine powder with a Dangoumau grinder for total RNA extraction. The remaining oysters were reared in the same experimental conditions. Dead oysters were counted daily and removed from the experimental raceway.

\subsection{Bacterial challenge}

A bacterial challenge was carried out at $19^{\circ} \mathrm{C}$ (November 2003) as described in Montagnani et al. (2002). Vibrio splendidus was grown overnight at $24^{\circ} \mathrm{C}$ in marine broth. Bacterial cells were collected by centrifugation (3500 rpm, $15 \mathrm{~min}$ ), washed and resuspended in 10ml sterile seawater. Two-year-old oysters from the same R and S progeny described above were challenged by injecting either $100 \mu \mathrm{l}$ of sterile seawater (isw) or $100 \mu \mathrm{l}$. splendidus into the adductor muscle. Sixty oysters were injected with $V$. splendidus (iv), 60 with sterile seawater (isw) and a further 60 were untreated (ni). The oysters were then returned to seawater raceways for $10 \mathrm{~h}$ after which time the mantle-gonad was dissected from 25 oysters per group and total RNA extracted. The remaining 35 oysters in each group continued to be reared under the same experimental conditions. Dead oysters were counted daily and removed from the experimental raceways.

\subsection{RNA extraction}

Total RNA was isolated using Trizol reagent (Gibco BRL) at a concentration of $1 \mathrm{ml} / 50 \mathrm{mg}$

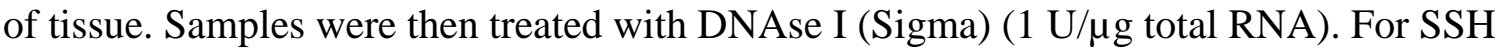
experiments, polyadenylated RNA was isolated using the Quickprep micro mRNA purification kit (Amersham). RNA concentrations were measured at $260 \mathrm{~nm}$ using the conversion factor $1 \mathrm{OD}=40 \mu \mathrm{g} / \mathrm{ml}$ RNA, and RNA quality was checked by electrophoresis through a denatured agarose gel. 


\subsection{Suppression subtractive hybridization}

mRNA extracted from the mantle-gonad tissue of R or S oysters was pooled and $2 \mu \mathrm{g}$ of each pool used as the template for SSH following the PCR-select cDNA subtraction kit procedure (Clontech). Hybridization and subtraction steps were carried out in both directions, i.e. for forward subtraction the R sample (tester) was subtracted with the S sample (driver) and vica versa for reverse subtraction. The PCR products from the forward subtraction were cloned into pCR 2.1® TOPO plasmid using TOP10 One Shot ${ }^{\circledR}$ competent cells for transformation (Invitrogen).

\subsection{Screening of the subtracted clones}

To eliminate cDNA clones common to both the R (tester) and S (driver) samples in the subtracted tester, a PCR-select method (Diatchenko et al., 1999) was employed on subtracted clones following the recommendations of the PCR-select differential screening kit (Clontech). Inserts cloned into pCR 2.1 were amplified by PCR using adaptor specific primers. Each PCR product was blotted onto Hybond-N+ nylon membranes (Amersham) in duplicate after denaturation by adding one volume of $0.6 \mathrm{~N} \mathrm{NaOH}$. Oyster actin was cloned $(\underline{\mathbf{A F 0 2 6 0 6 3}})$ and blotted in duplicate onto each nylon membrane after PCR amplification. DNA was crosslinked to the membrane at $70^{\circ} \mathrm{C}$ for $2 \mathrm{~h}$. In total, 7 different membranes were prepared in quadruplicate for hybridization with 4 different cDNA probes corresponding to the forwardsubtracted probe, the unsubtracted tester probe, the reverse-subtracted probe and the unsubtracted driver probe. After RsaI digestion, probes were prepared using the Ready-to-go DNA labelling beads [-dCTP] kit (Amersham) and $50 \mu \mathrm{Ci} \alpha-\mathrm{P}^{32} \mathrm{CTP}$. The labelled probes were purified from unincorporated dNTPs using AutoSeq G-50 columns (Amersham). The specific activity of each probe was measured using a scintillation counter (Packard Instruments, France) after TCA precipitation. 
Membranes were prehybridized for $1 \mathrm{~h}$ at $42^{\circ} \mathrm{C}$ in $50 \%$ deionised formamide, $5 \mathrm{x}$ SSC, $5 \mathrm{x}$ Denhardt's, 0.5\% SDS and $100 \mu \mathrm{g} / \mathrm{ml}$ denatured herring sperm DNA. Hybridization was performed overnight at $42^{\circ} \mathrm{C}$ in prehybridization buffer containing the radio-labelled probe. After hybridization, membranes were washed for $20 \mathrm{~min}$ at $68^{\circ} \mathrm{C}$ in prewarmed lowstringency solution (2x SSC/0.5\% SDS) and then twice for $20 \mathrm{~min}$ at $68^{\circ} \mathrm{C}$ in prewarmed high-stringency solution (0.2x SSC/0.5\% SDS). Membranes were then exposed to autoradiographic film (Kodak Biomax MS). The signal intensity was quantified using Multianalyst software (Biorad, CA) with the background signal removed. The value obtained is the spot intensity expressed as mean count per pixel and multiplied by the spot surface area. Clones were sequenced using an ABI Prism Big Dye Terminator Cycle Sequencing kit (PE Applied Biosystems). Database searches were carried out using the BlastX program (http://www.ncbi.nlm.nih.gov/BLAST/). BlastN analyses were carried out using the specific oyster database “GigasBase” (Gueguen et al., 2003). Only E-values less than $10^{-2}$ were considered significant. Contigs were built using the CAP3 assembly program (Huang and Madan, 1999).

\subsection{Full length cDNA}

A cDNA library constructed in $\lambda$-ZAP II from $C$. gigas mantle-edge mRNA was screened as described by Lelong et al. (2000). Specific primers, and where required, nested primers, were designed for selected cDNAs (Table 1). Amplified fragments were subcloned into pCR 2.1®) TOPO plasmid and sequenced as described above.

\subsection{Real-time PCR analysis of gene expression}

The expression level of 8 mRNA transcripts were investigated by real time PCR using an Icycler (Biorad). One microgram of total RNA isolated from oysters inoculated with either $V$. 
splendidus or seawater or from unchallenged oysters were reverse-transcribed as described by Huvet et al. (2003) and amplified by real time PCR using specific primers (Table 1). 
Table 1. Primers used for the screening of the cDNA library and real-time PCR assay.

\begin{tabular}{|c|c|c|}
\hline cDNA & Primers & Oligonucleotide sequences (5' - 3') \\
\hline \multirow[t]{4}{*}{ cavortin } & Cav_qf & CTT CAT gCC Agg CAA CCT \\
\hline & Cav_qr & TgA CgT TgA ATC Cgg TCA \\
\hline & Cav_1f & gAg Agg TgA Atg CTA CCA ggA CTT TC \\
\hline & Cav_1r & ACA gAC AgA AgC TCA TTT CCA AAg \\
\hline \multirow[t]{4}{*}{ fatty acid binding protein } & Fab_qf & CAC gAA ggg ACC CAA AgA \\
\hline & Fab_qr & CAT gTg ACC Agg gCC TTC \\
\hline & Fab_1f & AAT ACT gAT gTC TgA ggg ACT TTg T \\
\hline & Fab_1r & CTg gCA TTg TCC CAT ATA TCA AC \\
\hline \multirow[t]{5}{*}{ sodium glucose cotransporter } & Glt_qf & Cgg AAg gCT gTg TgT CCT \\
\hline & Glt_qr & gAg gTg ATg gCC Tgg ATg \\
\hline & Glt_1f & ACg Tgg gAC TTC TTT CTT TAg ATg \\
\hline & Glt_1r & Tgg gCT gAg AAT TAA gTA AgT TgC \\
\hline & Glt_4r & ACT ACC gCA CTC TCT CTC ACA AAT A \\
\hline \multirow[t]{3}{*}{ cyclophilin } & Cyc_qf & CgC Cgg TAg gAT TgT CAT \\
\hline & Cyc_qr & AgC CAA AgC CTT TCT СТC CT \\
\hline & Cyc_1f & CTTCAgCTggAAgTTCTCATCAg \\
\hline \multirow[t]{4}{*}{ isocitrate dehydrogenase } & Idh_qf & CCg ACg gAA AgA CTg TCg \\
\hline & Idh_qr & CTg gCT ACC ggg TTT gTg \\
\hline & Idh_1f & gCAggATACAAAACCgTgTgAC \\
\hline & Idh_1r & AgCTATTAgTTCACACCCgAGTTC \\
\hline \multirow[t]{2}{*}{ atpase $H+$ transporting lysosomal protein } & Atp_qf & ggC gAC ATg gAg AgC AAg \\
\hline & Atp_qr & TCT CTT gAg TgC CAC CTC CT \\
\hline$\underline{\text { CK172358 }}$ & Lin_qf & CAA gAg CTT ggA CTT Tgg gTA \\
\hline \multirow[t]{4}{*}{ (putative precerebellin) } & Lin_qr & CAA AgA gCT ATg ACC gAg Tgg \\
\hline & Lin_2f & gAT TTC AAA gAg CTA TgA CCg AgT \\
\hline & Lin_1r & CTg TgT CAA TAg ATg Agg CAT TTC \\
\hline & Lin_2r & ACT TAg TAg CCT CCT TgT gAC ACC \\
\hline$\underline{\text { CK172401 }}$ & Sca_qf & ATg TgC Agg TCA gCA TTg TAA \\
\hline \multirow[t]{4}{*}{ (putative scavenger-receptor) } & Sca_qr & TCT CCC TCC TCC TTT gAT TCT \\
\hline & Sca_1f & AАТ АTC ААТ СТС ССТ ССТ ССТ TTg \\
\hline & Sca_1r & ACT ggg Agg AAT TgA TCT TAC TTg \\
\hline & Sca_2r & CTg TAC AAC TTC CAT TCC AAC AAg \\
\hline
\end{tabular}

r: reverse primer; f: forward primer; q: indicated primers used for the real time PCR analysis. Other primers were used for the screening of the cDNA library. 
Amplification of actin and elongation factor I cDNAs were performed in order to confirm the steady-state level of expression of a housekeeping gene to provide an internal control for gene expression. Actin and elongation factor I primers were those used by Huvet et al. (2003) and Fabioux et al. (2004) respectively.

The real-time PCR assay was performed in triplicate with $5 \mu \mathrm{L}$ cDNA (1/10 dilution) in a total volume of $15 \mu \mathrm{L}$. The concentrations of the reaction components were as follows: 0.33 $\mu \mathrm{M}$ each primer, $1.5 \mu \mathrm{L}$ fluorescein and 1X Quantitect SYBR Green PCR kit (Qiagen). This reaction was performed using Taq Polymerase as follows: activation at $95^{\circ} \mathrm{C}$ for $15 \mathrm{~min}$ followed by 45 cycles of $30 \mathrm{sec}$ at $95^{\circ} \mathrm{C}, 1 \mathrm{~min}$ at $60^{\circ} \mathrm{C}$, and a melting curve program from $95^{\circ} \mathrm{C}$ to $70^{\circ} \mathrm{C}$ by decreasing the temperature $0.5^{\circ} \mathrm{C}$ every 10 seconds. Each run included a positive cDNA control (one S sample of the present experiment analyzed in each amplification plate), negative controls (each total RNA sample with DNAse I treatment) and blank controls (water) for each primer pair. PCR efficiency (E) was determined by drawing standard curves from a serial dilutions analysis of cDNA from R and S samples to ensure that E ranged from 99 to $100 \%$ for each primer pair.

The calculation of relative mRNA levels was based on the comparative Ct method (Livak and Schmittgen, 2001). No significant differences between Ct values were observed for the two house keeping genes (actin, elongation factor I), between R and S samples or between injected and non injected oysters (t-test after Bonferroni adjustment: $P=0.151$ and 0.085; coefficient of variation $=3.4$ and $3.5 \%$ for actin and elongation factor $I$, respectively). Therefore, the relative quantification value of the sample was normalized to the actin gene (because of its lower coefficient of variation) and relative to the positive control, and was expressed as $2^{-\Delta \Delta \mathrm{Ct}}$, where $\Delta \mathrm{Ct}=[\mathrm{Ct}(\mathrm{cDNA}$ sample $)-\mathrm{Ct}($ positive cDNA control $)]$ and $\Delta \Delta \mathrm{Ct}$ $=\Delta \mathrm{Ct}$ of cDNA $-\Delta \mathrm{Ct}$ of actin. Comparison of the level of mRNA (relative to actin mRNA) between R and S progeny was performed by Student's $t$-test using SYSTAT 9.0 by SPCC. 
Multiple comparisons of the level of mRNA (relative to actin mRNA) between injected and non-injected groups were performed within sibling progeny by analysis of variance using the least significant difference (LSD) pairwise multiple comparisons test using the same software.

\section{Results}

\subsection{Experimental conditioning}

In April 2002, F2 progeny from 6 oyster families selected as either resistant (R) or susceptible (S) to summer mortality were placed in the same experimental raceway and maintained under the same conditions. The first oysters died on July $4^{\text {th }} 2002$ and one week later the cumulative mortality was estimated at $74.5 \pm 11.0 \%$ and $4.1 \pm 3.2 \%$ for the S and R progeny respectively. Bacterial analysis identified Vibrio splendidus as making up 50 to $80 \%$ of the total bacterial population of the dying S oysters. In live R and S oysters, however, a greater diversity in the bacterial population was observed (data not shown).

\subsection{Suppression Subtractive Hybridization}

Tester mRNA obtained by forward subtraction was used to construct a subtracted cDNA library. In total, 376 clones were isolated (Table 2). To eliminate cDNA clones common to both the R (tester) and S (driver) samples, all the subtracted clones were arrayed after PCR amplification onto nylon membranes and hybridized with 4 different probes (forwardsubtracted probe, unsubtracted tester probe, reverse-subtracted probe and unsubtracted driver probe). Mean spot intensity were attributed to each clone for each probe allowing their classification into 2 categories:

(1) clones that hybridized only to the forward-subtracted probe; clones that hybridized to the forward-subtracted probe and unsubtracted tester probe but not to the reverse-subtracted probe or unsubtracted driver probe and clones that hybridized to both subtracted probes 
when the difference of signal intensity was higher than 3. The 150 clones (40\%) classified into this category were confirmed by PCR-select to be differentially expressed, their expression being induced in R compared to S progeny.

(2) clones that hybridized to both subtracted probes when the difference of signal intensity was equal to or lower than 3; clones that hybridized equally to both subtracted probes and to both unsubtracted probes. In this category, 226 clones (60\%) were considered as false positive or non-differentially expressed clones. The actin clone was classified into this second category with similar values of mean spot intensity in the R and S samples (mean value $=0.37$ and 0.33 , respectively)

The nucleotide sequence of the 150 clones from category 1 was established: $28 \%$ matched with products of known genes (42 sequences); 14\% matched hypothetical proteins (21 sequences); 14\% displayed ORFs of significant length but whose product was unknown (21 sequences), 35\% appeared to be non coding sequences (53 sequences) and 9\% were unreadable sequences (13 sequences which were then excluded from the analysis). Genbank

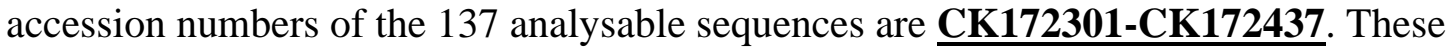
sequences have a mean size of 452 bp and coalesced into 74 singletons and 22 contigs indicating a redundancy of 30\% among the 137 clones sequenced (Table 2). 
Table 2. General characteristics of the subtracted library and cDNA sequences from C. gigas mantle-gonad.

Total number of subtracted clones

Total number of differentially expressed clones (confirmed with blots)

Total number of cDNA sequences deposed in Genbank

Average sequence size

$452 \mathrm{bp}$

(range)

ORF

Contigs

Among the 42 sequences that matched with the products of known genes (Table 3), 25 were unique and clustered into 6 categories (Figure 1): 24\% were active in general metabolism, $12 \%$ in energy metabolism, $20 \%$ in cell signalling, cell cycle and cell structure, $16 \%$ in putative immune functions, $16 \%$ in ribosomal proteins and $12 \%$ in replication, repair and transcription of DNA. Among the 22 identified contigs, 9 matched with the products of known genes. These were isocitrate dehydrogenase, sarcoplasmic calcium-binding protein, cytochrome C oxidase, tRNA splicing phosphotransferase, DNA topoisomerase, DNA replication factor, bone morphogenic protein, KIAA1007 protein and 28S mitochondrial ribosomal protein. Three contigs encoded proteins with no known function and 10 displayed ORFs of significant length but whose hypothetical product did not match any sequence in Genbank. 
Figure 1. Functional classification of the SSH sequences which matched with known genes (42 sequences corresponding to 25 unique genes). They were clustered into 6 categories according to their putative biological function.

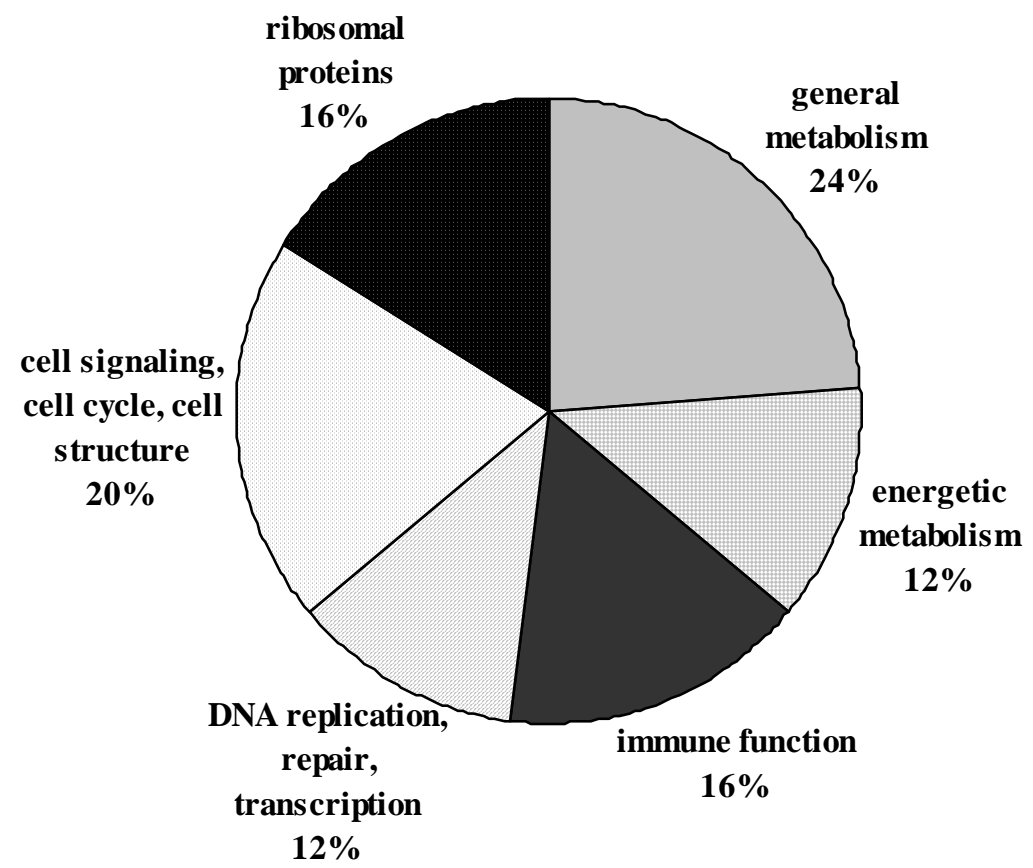


Table 3. Identified cDNAs clones in oyster subtracted library.

\begin{tabular}{|c|c|c|c|c|}
\hline Putative match & Species match & E value & Length & Accession number \\
\hline Cavortin & Crassostrea gigas & $\begin{array}{c}6 e-28 \\
1 e-89 *\end{array}$ & $\begin{array}{c}353 \\
194 \text { aа* }^{*}\end{array}$ & $\frac{\text { CK172315 }}{\underline{\mathrm{AY}} 551094^{*}}$ \\
\hline $\begin{array}{l}\text { Peptidyl-prolyl cis-trans } \\
\text { isomerase (Cyclophilin) }\end{array}$ & $\begin{array}{c}\text { Mus musculus } \\
\text { Blattella germanica * }\end{array}$ & $\begin{array}{c}6 e-52 \\
1 e-69 *\end{array}$ & $\begin{array}{c}841 \\
164 \text { aа * }\end{array}$ & $\frac{\text { CK172388 }}{\text { AY551095* }^{*}}$ \\
\hline Isocitrate dehydrogenase & $\begin{array}{l}\text { Homo sapiens } \\
\text { Danio rerio * }^{*}\end{array}$ & $\begin{array}{c}7 e-12 \\
1 e-174 *\end{array}$ & $\begin{array}{l}\text { 735, } 735, \\
739 \\
470 \mathrm{aa}^{*}\end{array}$ & $\frac{\text { CK172330, CK172366, }}{\underline{\text { AY } 172386}^{*}}$ \\
\hline Fatty acid binding protein & Myotis lucifugus & $\begin{array}{c}4 \mathrm{e}-4 \\
5 \mathrm{e}-16 *\end{array}$ & $\begin{array}{c}386 \\
141 \text { aа * }\end{array}$ & 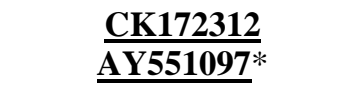 \\
\hline $\begin{array}{l}\text { Sodium glucose } \\
\text { cotransporter }\end{array}$ & Homo sapiens & $\begin{array}{c}2 \mathrm{e}-2 \\
1 \mathrm{e}-162^{*}\end{array}$ & $\begin{array}{c}523 \\
653 \text { aа * }\end{array}$ & $\frac{\text { CK172416 }}{\underline{\mathrm{AY}} 551098^{*}}$ \\
\hline $\begin{array}{l}\text { Atpase } \mathrm{H}+\text { transporting } \\
\text { lysosomal protein }\end{array}$ & Caenorhabditis elegans & $\begin{array}{c}4 \mathrm{e}-7 \\
4 \mathrm{e}-7\end{array}$ & $\begin{array}{l}412 \\
61 *\end{array}$ & $\frac{\text { CK172372 }}{\underline{\mathrm{AY} 551099}^{*}}$ \\
\hline \multirow{2}{*}{ Scavenger-receptor } & Sus scrofa & $1.5 e-1$ & 296 & $\underline{\text { CK172401 }}$ \\
\hline & $\underline{\text { BQ426240 (C. gigas) }}$ & $1 \mathrm{e}-144$ & & \\
\hline \multirow{2}{*}{ Precerebellin } & Oncorhynchus mykiss & 4.8 & 756 & CK172358 \\
\hline & $\underline{\text { BQ426725 }}$ (C. gigas) & $7 e-12$ & & \\
\hline PP2A inhibitor & Tetraodon fluviatilis & 3e-18 & 600 & CK172303 \\
\hline $\begin{array}{l}\text { DNA replication licensing } \\
\text { factor mcm5 (cdc46 homolog) }\end{array}$ & Xenopus laevis & $5 e-69$ & 498 & $\underline{\text { CK172304, CK172410 }}$ \\
\hline Putative Cutinase & Phytophthora capsici & $6 e-11$ & 243 & CK172308 \\
\hline $\begin{array}{l}\text { Sarcoplasmic calcium-binding } \\
\text { protein }\end{array}$ & $\begin{array}{c}\text { Mizuhopecten yessoensis } \\
\text { Meretrix lusoria }\end{array}$ & $\begin{array}{c}3 e-4 \\
6 e-4 \\
1 e-44\end{array}$ & $\begin{array}{l}357 \\
322 \\
517\end{array}$ & $\frac{\text { CK172313, }}{\frac{\text { CK172314 }}{\text { CK172346 }}}$ \\
\hline NADH Dehydrogenase 6 & Crassostrea gigas & $2 e-29$ & 495 & $\underline{\text { CK172316 }}$ \\
\hline $\begin{array}{l}\text { tRNA splicing 2' } \\
\text { phosphotranferase }\end{array}$ & Homo sapiens & $\begin{array}{l}4 e-39 \\
7 e-39\end{array}$ & $\begin{array}{l}722 \\
723\end{array}$ & $\frac{\mathrm{CK} 172320}{\mathrm{CK} 172355}$ \\
\hline Cytochrome C Oxidase & Crassostrea gigas & $6 e-68$ & 804 & CK172365 \\
\hline DNA Topoisomerase I & Homo sapiens & $\begin{array}{l}7 e-12 \\
1 e-3 \\
6 e-11 \\
3 e-12 \\
2 e-14 \\
2 e-16 \\
2 e-10\end{array}$ & $\begin{array}{l}363 \\
371 \\
369 \\
363 \\
422 \\
363 \\
365\end{array}$ & $\begin{array}{l}\text { CK172310 } \\
\text { CK172354 } \\
\text { CK172360 } \\
\text { CK172369 } \\
\text { CK172383 } \\
\text { CK172406 } \\
\text { CK172430 } \\
\end{array}$ \\
\hline Bone Morphogenic Protein & Dugesia japonica & $\begin{array}{l}8 e-7 \\
8 e-7\end{array}$ & $\begin{array}{l}703 \\
702\end{array}$ & $\frac{\mathrm{CK} 172353}{\mathrm{CK} 172362}$ \\
\hline $\begin{array}{l}\text { Gamma-kafirin preprotein } \\
\text { precursor }\end{array}$ & Sorghum bicolor & $3 e-2$ & 648 & $\underline{\text { CK172377 }}$ \\
\hline Glycoprotein 120 & $\begin{array}{l}\text { Crassostrea gigas } \\
\text { (BQ427259) }\end{array}$ & $8 e-7$ & 366 & CK172407 \\
\hline Kiaa1007 protein & Homo sapiens & $\begin{array}{l}5 e-34 \\
5 e-38\end{array}$ & $\begin{array}{l}392 \\
391\end{array}$ & $\frac{\mathrm{CK} 172341}{\mathrm{CK} 172418}$ \\
\hline
\end{tabular}


Poly(a)-specific ribonuclease

S8 ribosomal protein

28S mitochondrial ribosomal protein S18c

40S ribosomal protein s15a

Ribosomal protein L34
Rattus norvegicus

Drosophila melanogaster

Drosophila melanogaster

Drosophila melanogaster

Branchiostoma belcheri tsingtaunese

$\begin{array}{ll}\text { 4e-41 } & 845 \\ 6 e-42 & 470 \\ \text { 1e-19 } & 514 \\ 8 e-11 & 522 \\ 1 e-19 & 514 \\ \text { 1e-58 } & 470 \\ \text { 3e-21 } & 171\end{array}$

845

CK172399

CK172301

CK172352, CK172379

CK172391

CK172415

CK172414

CK172385

cDNAs appearing in bold were extended ( $v$-atpase cDNA is not complete), and their full length (in aa), E-value and Genbank accession number are reported with *.

\subsection{Sequence and expression analysis of ESTs implicated in energy generation or immune function}

The transcripts clustered into categories corresponding to energy generation or immune function were fully sequenced and found to encode homologues of the following proteins: cavortin ( $\underline{\mathbf{A Y 5 5 1 0 9 4}})$, cyclophilin (PPIase, $\underline{\mathbf{A Y 5 5 1 0 9 5}})$, isocitrate dehydrogenase (IDH,

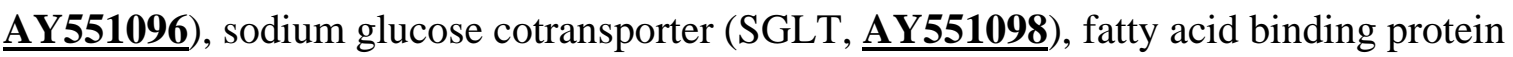
(FABP, $\underline{\text { AY551097) }}$ and ATPase H+ transporting lysosomal protein (V-ATPase; $\underline{\text { AY551099). }}$. Clones showing doubtful homology with scavenger receptor (SR, $\underline{\text { CK172401) }}$ and precerebellin ( $\underline{\mathbf{C K 1 7 2 3 5 8}}$ ), two proteins reported to have a role in immune function, were also extended. After the extension of these two clones, no significant homology of sequence was found in databases (E-value $>0$ ).

For these 8 transcripts, the mRNA level of the samples used for the SSH was estimated by real time PCR and was significantly higher (relative to the actin transcript) in the R compared to the S progeny at the $5 \%$ level for cavortin, ppiase, idh, putative-precerebellin, and at the $1 \%$ level for putative-sr, sglt, fabp, $v$-atpase. The mean additional expression observed in the R progeny was $1.7 \pm 0.4$ ranging from 1.28 to 2.57 for cavortin and fabp respectively (Figure 2). 
Figure 2. The amount of gene transcript relative to actin transcript in susceptible (S, black bar) and resistant (R, black plus grey bars) progeny. The additional amount of relative gene expression in $\mathrm{R}$ families compared to $\mathrm{S}$ families is represented by the grey bars and is significant at the $5 \%$ level for all the measured genes (Student's $t$ test). The error bars represent one standard deviation of that additional amount.

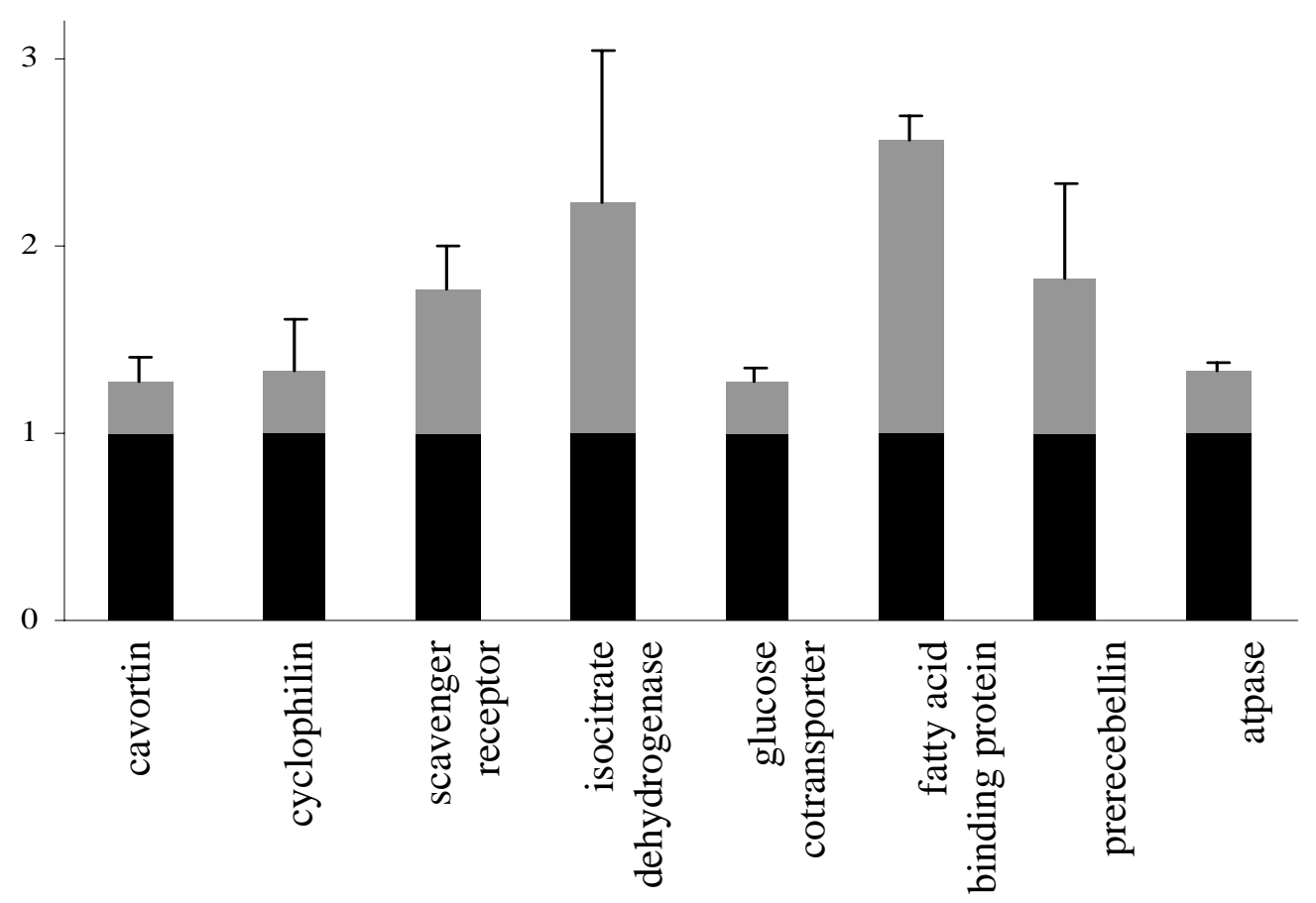

\subsection{Bacterial challenge}

Gene expression analysis of the 8 selected transcripts showed the level of 6 (ppiase, idh, sglt, fabp, v-atpase, putative-sr, Figure 3) of the transcripts to be significantly higher in the non injected-R (ni-R) group compared to the non injected-S (ni-S) group at the $5 \%$ level. The mean additional expression observed in the ni-R group was $1.6 \pm 0.1$ ranging from 1.5 to 1.7 for idh and sglt, respectively. mRNA levels of cavortin and putative-precerebellin relative to actin transcript, were not significantly different between the ni-R and ni-S groups $(P>0.05)$. To try to reproduce the particular summer mortality event we observed in the first experiment, a bacterial challenge was carried out with $V$. splendidus isolated during this event. Ten hours after challenge, significant changes in the mRNA level (relative to actin mRNA) were reported between ni-S and challenged S groups for sglt, cavortin and idh only. The level of cavortin and idh transcripts decreased in injected-vibrio-S (iv-S) compared to ni-S whereas a 
slight significant increase of sglt transcript (1.4-fold higher) was observed in iv-S compared to ni-S $(P=0.018)$. In contrary, in R progeny significant reductions in mRNA levels (relative to actin mRNA) were reported in injected-Vibrio-R (iv-R) compared to ni-R for all 8 genes. These reductions ranged from 1.7 to 7.2-fold for cavortin and v-atpase respectively (mean decrease $=3.3 \pm 1.9$ ) (Figure 3). Furthermore, significant reductions were also observed in injected-seawater-R (isw-R) compared to ni-R for 5 different transcripts (idh, sglt, v-atpase, putative-sr, putative-precerebellin). These reductions were less intense (mean decrease $=1.7$ \pm 0.7 ) compared to those measured between iv-R and ni-R but no significant differences were observed between iv and isw mRNA levels.

Four days after injection, cumulative mortality was $79.5 \pm 12.0 \%$ and $72 \pm 9.0 \%$ for iv-R and iv-S progeny respectively. No mortality was observed in uninjected oysters or oysters injected with sterile seawater. 
Figure 3. The amount of gene transcript relative to actin transcript in resistant (R) and susceptible (S) progeny 10 hours after challenge. Oysters were injected with either Vibrio splendidus (black bars), sterile seawater (hatched bars) or not injected (grey bars). The error bars represent one standard deviation. Comparison of the level of mRNA (relative to actin mRNA) between non-injected R and S groups was performed by Student's $t$-test; (*) significant at the $5 \%$ level. Homogenous groups were estimated within progeny between injected and non injected groups using the least significant difference (LSD) pairwise multiple comparisons test.

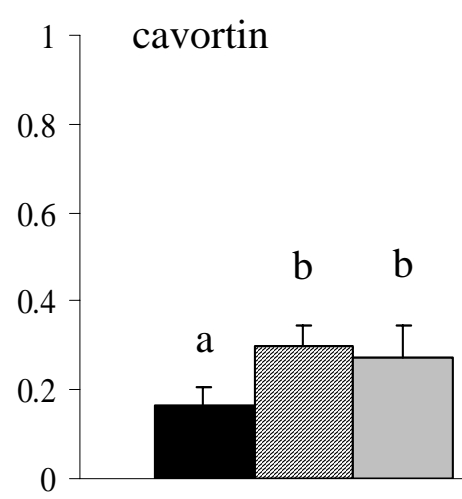

$\mathrm{R}$

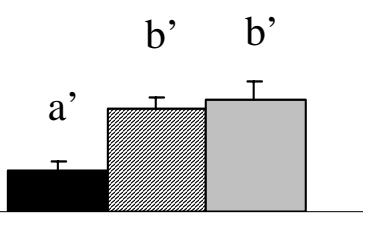

S

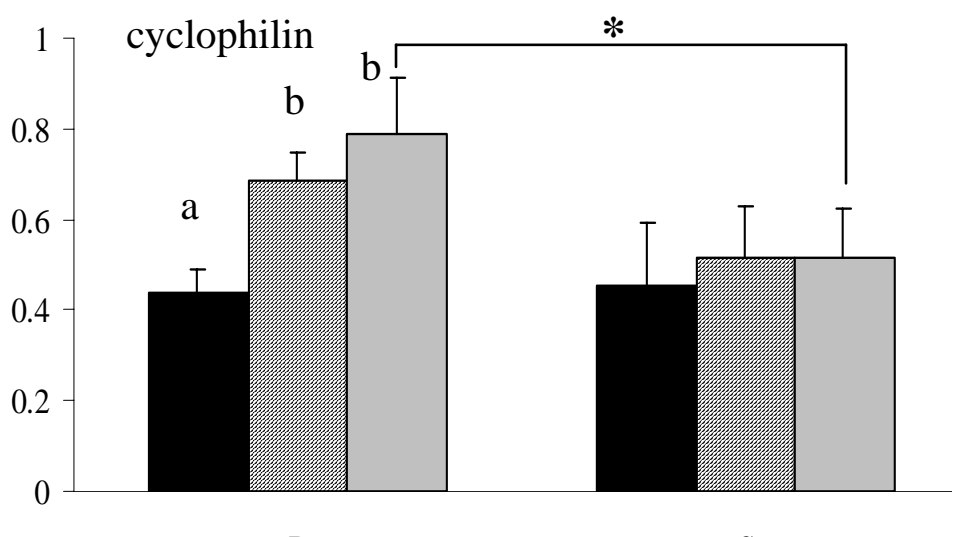

$\mathrm{R}$

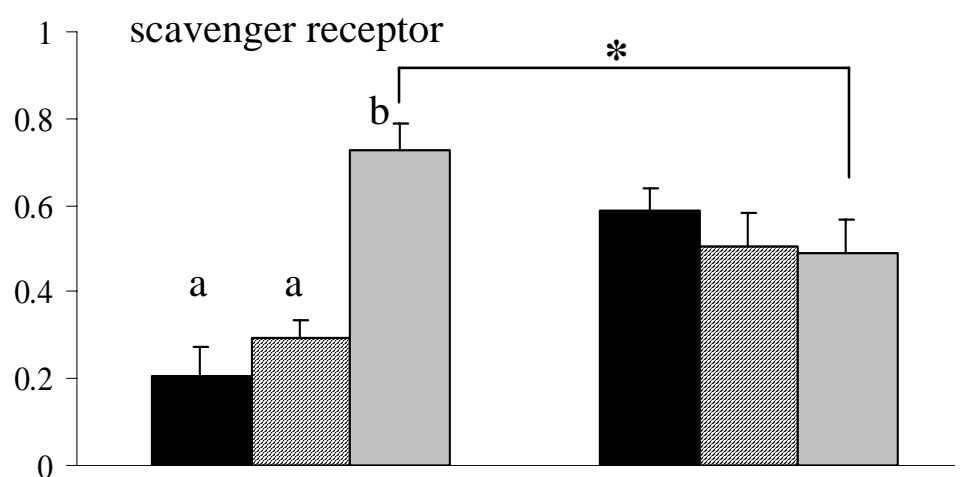

$\mathrm{R}$

S

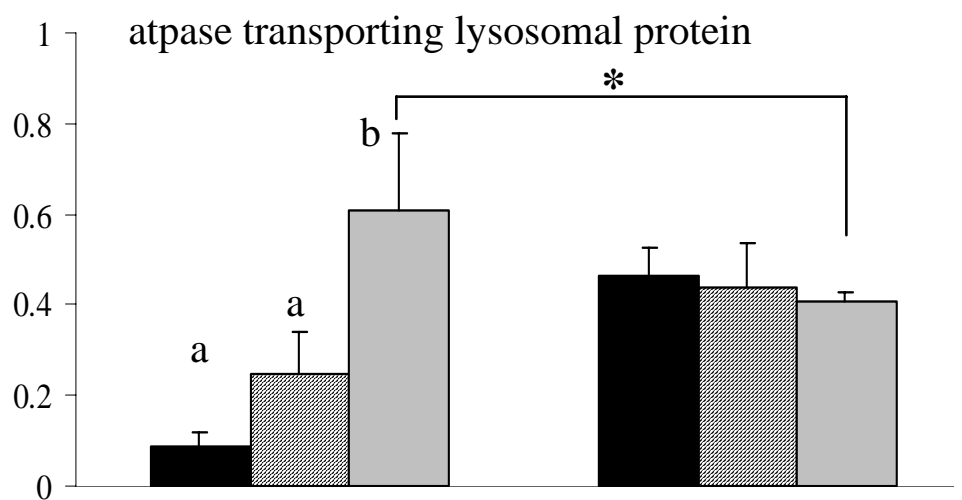

$\mathrm{R}$

S

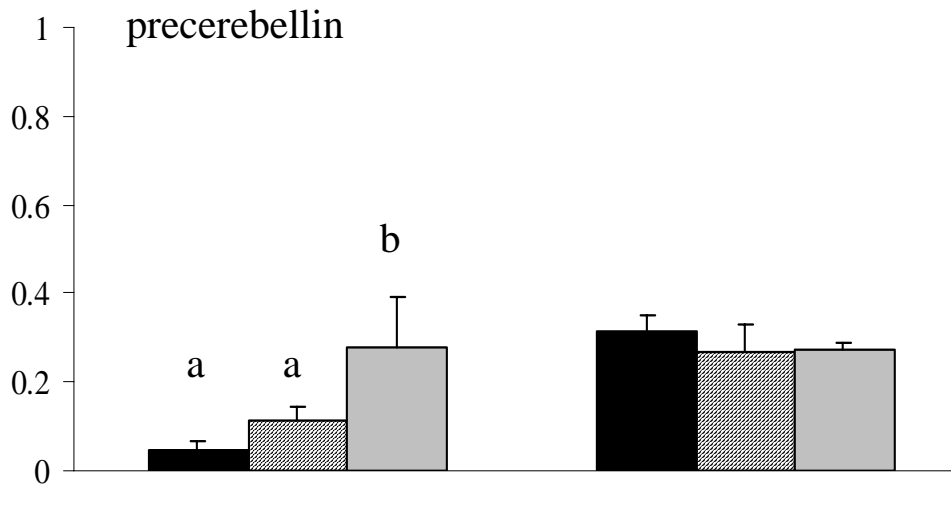

R

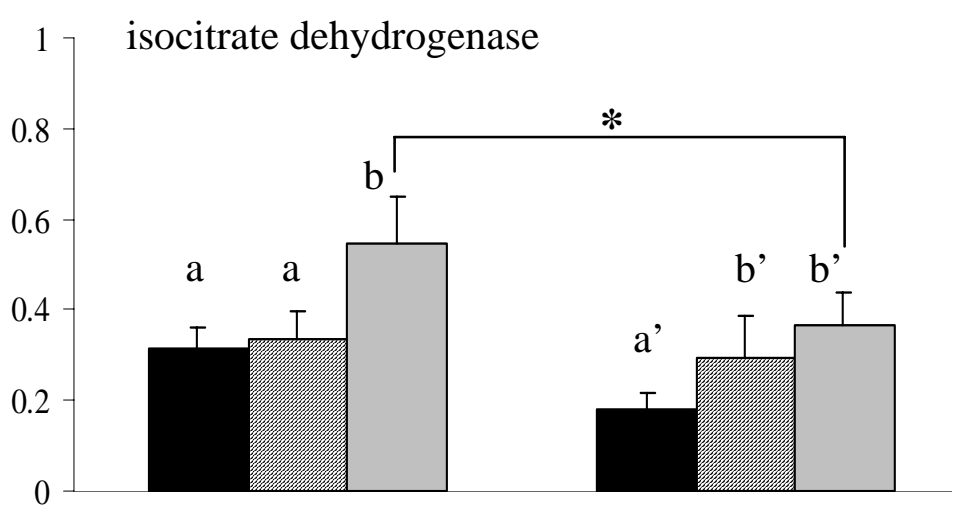

R
S
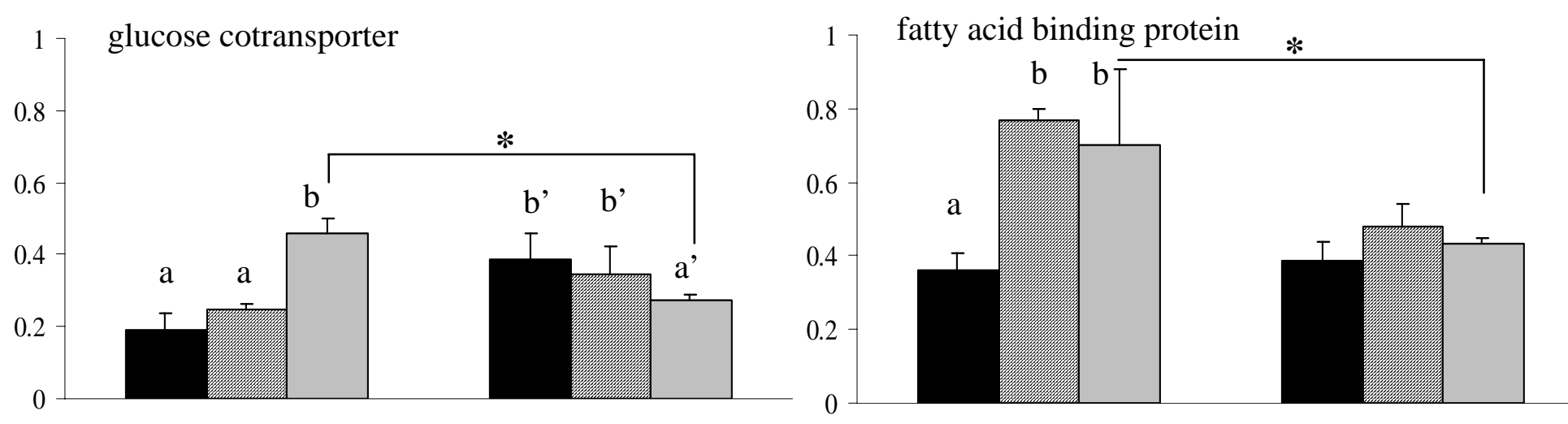

R S 


\section{Discussion}

\subsection{Suppression subtractive hybridization}

SSH was conducted in the present study using C. gigas R and S F2 progeny obtained following divergent selection criteria (Dégremont et al., 2003). Three hundred and seventy six clones were obtained in the subtracted library and the differential expression of these clones was confirmed for 150 using a PCR-select method (Diatchenko et al., 1999). The remaining 60\% represent non-differentially expressed 'background' transcripts and were therefore eliminated from the analysis. An enhanced level of mRNA expression in the R compared to the S progeny was then confirmed for 8 selected transcripts by real time PCR. For example there was a 1.3 to 2.6-fold enhancement of expression in the R progeny for cavortin and fabp respectively.

\subsection{Induced genes in $R$ compared to $S$ progeny}

BlastX analysis of the 150 partially sequenced differentially regulated clones resulted in 25 unique homologues being identified (Table 3) of which 16 have never been reported previously in any marine bivalve species. These genes appeared to be divided into 6 functional categories, including general metabolism, cell signaling, cell cycle and cell structure, and DNA replication, repair and transcription. Based on published data related to summer mortality in mussels (Tremblay et al., 1998) and on initial data from the 'Morest' program (non shown), it has been hypothesized that C. gigas summer mortality is the result of an energetic and/or immunological dysfunction. Twelve and $16 \%$ of the characterized cDNA clones respectively were in these categories. The nucleotide sequence of 8 cDNAs which were classified as being involved in either energy metabolism or putative immune function were extended. Transcripts encoded homologues of the following proteins: Cavortin, PPIase, IDH, SR, Precerebellin, V-ATPase, SGLT and FABP. For Cavortin, PPIase, IDH, V-ATPase, 
SGLT and FABP, extending their cDNA sequences to full length size (cDNA sequence of VATPase is not complete) confirmed their identity. However, extending the two other cDNA sequences changed the doubtful identity of cDNAs encoding homologues of SR and Precerebellin to having no significant homology (Table 3).

Based on the function of some genes identified in the subtracted library, energy and especially its mobilization would appear to be a key difference between the R and S progeny. Reported SSH sequences encoded SGLT and FABP; SGLT mediates glucose uptake into cells driven by a $\mathrm{Na}^{+}$gradient (Wright, 2001) and is of major importance in the sustenance of a cell’s energetic requirement. FABP is a cytosolic protein involved in the uptake, transport and compartmentalization of fatty acids (Dhar et al., 2003) and would be stimulated under a variety of circumstances for mobilization of lipid to provide the metabolic fuel required. In our initial experiment in which the cumulative mortality of S and R progeny reared in summer conditions with a plentiful food supply was determined, we found $V$. splendidus to comprise up to 50 to $80 \%$ of the total bacterial population of the dying S oysters. In contrast, R progeny displayed a high survival rate under the same conditions. This result is additional evidence for the strong genetic basis of the survival observed in the divergent selection criteria applied (Dégremont et al., 2003). Immune function might therefore be another difference between R and S progeny. Some subtracted transcripts encoded proteins implicated in immune pathways such as Cyclophilin, a peptidylprolyl isomerase known in mammals to accelerate the folding of proteins and to mediate signalling events leading to T-cell activation (Shida et al., 2003). In the case of bacterial infection, a cellular immune response is engaged in the host initially when SR and/or Toll-like receptors on haemocyte membranes recognize

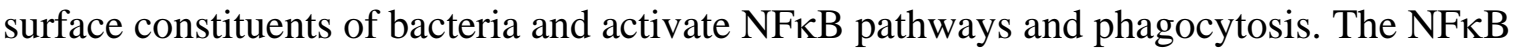
pathway can also be stimulated by inflammatory cytokines such as bone morphogenic protein (BMP)-4 (Sorescu et al., 2003). A member of the BMP family was characterised in our 
subtracted oyster library and clone $\underline{\text { CK172329 }}$ matched with Toll-8 but without significant blast value. When pathogens are phagocytosed, haemocytes produce reductive oxygen intermediates (ROIs) that together with lysosomal cytotoxic components kill pathogens. Lysosomal processes require acidification of the intracellular compartment (Forgac, 1999). This is the function of V-ATPase, a multisubunit enzyme characterised in the subtracted library. ROIs produce oxidative damage to biological macromolecules such as DNA, RNA, protein and lipids. A greater capacity to rapidly detoxify the ROIs could perhaps explain differences in oyster survival rather than the capacity of haemocytes to synthetize ROIs. Some subtracted cDNAs encoding Cytochrome C oxidase, IDH and Cavortin, may contribute to cellular host protection against ROIs: IDH is able to supply NADPH which is needed for GSH production (Ciriolo et al., 1997; Kim and Park, 2003) and Cytochrome C oxidase converts molecular oxygen into water in the mitochondrial respiratory chain (Tian et al., 1998). Furthermore, Cavortin, recently characterized as a self-aggregating haemolymph glycoprotein in mussel (called Pernin), has a superoxide dismutase (SOD) domain (Scotti et al., 2001). SOD activity converts $\mathrm{O}_{2}{ }^{-}$to the less dangerous $\mathrm{H}_{2} \mathrm{O}_{2}$ and is needed to prevent host cellular oxidative damage. To date, no SOD activity has been found directly associated with cavortin but this is still under investigation (Scotti P., Pers. Comm.). The present study identified candidate genes implicated in the underlying physiological differences between $\mathrm{R}$ and S progeny. To begin to address their potential role in summer mortality and consequently identify pathway(s) that may significant to the higher rate of mortality of S progeny, we analyzed the expression of these genes in an in vitro experimental summer mortality event. 


\subsection{Bacterial challenge}

The relative levels of gene expression in unchallenged oysters showed that, irregardless of age, season or physiological status (i.e. resting period versus reproductive period), most of the measured transcripts (ppiase, idh, sglt, fabp, v-atpase, putative-sr) were induced in the $\mathrm{R}$ compared to the S progeny. This suggests fundamental functional differences between the two groups of progeny for those genes. This is the case for both cDNAs involved in energy mobilization (sglt, fabp) and for those such as ppiase, idh and v-atpase that are probably implicated in immune or cellular host protection against ROIs.

The high energetic cost associated with the reproductive process, when combined with high summer temperatures, are thought to weaken oysters and make them more susceptible to opportunistic pathogens possibly leading to death. This was bourn out by our preliminary conditioning experiment when $V$. splendidus comprised 50 to $80 \%$ of the total bacterial population of the dying $\mathrm{S}$ oysters. The identification of such relatively high levels $V$. splendidus in S oysters allowed us to carry out a bacterial challenge with this isolate with the aim of mimicking the observed experimental summer mortality event. Some transcripts (cavortin, idh), which are suggested to act in cellular host protection against ROIs, displayed a similar reduction in mRNA levels in R and S progeny in response to Vibrio inoculation. However, other transcripts (v-atpase, sglt, putative-sr, and putative-precerebellin) showed a significant decrease in gene expression solely in R progeny in response to Vibrio and seawater injections, probably corresponding to a general response to stress, and for which no downregulation in S progeny was observed. For two other transcripts, one probably involved in immune function (ppiase) and the second in energetic mobilization (fabp), the decrease of mRNA levels appeared to be specifically in response to inoculated bacteria and solely in $\mathrm{R}$ progeny. Such a decrease of mRNA levels was reported for penaeidin in shrimp during the first 12 hours following a bacterial challenge (Munoz et al., 2002). The authors suggested that 
this strong decrease was the result of the migration of haemocytes towards injured tissues and visualized by a massive accumulation of penaeidin-producing haemocytes around the site of injection. Here, the haemocytes constituted the main cellular mediators of the defence system but are also involved in the transport of nutrients in marine invertebrates (Cheng, 1996). If we extrapolate this observation to the present study we might hypothesize that the observed decrease of mRNA level in mantle-gonad tissue of challenged R oysters corresponded to mobilization of haemocytes towards the muscle where we injected Vibrio. Thus, a greater capability to rapidly recruit phagocytes towards infected tissues, kill pathogens and/or provide the metabolic fuel required for tissue regeneration would be expected in R oysters compared to S oysters. However, no difference was observed between $\mathrm{R}$ and S progeny in response to bacterial injection though both suffered a high mortality rate. Injecting $10^{8} \mathrm{~V}$. splendidus is generally fatal for oysters. Effects of lower doses, alternative method of bacterial challenge (close to natural infection), and temporal responses of oysters will be among our future experiments.

In conclusion, this work constitutes the first step towards elucidating the physiological and genetic basis of summer survival of R and S selected progeny. From the genes and pathways suggested to operate differentially between F2 S and R progeny, our data suggest fabp (lipid mobilization) and ppiase (immune mediation) expression during an infection episode as possible starting points for further research. Finally, a strong capacity to down-regulate some metabolic pathways was solely observed in R progeny after injection of pure sea water into the adductor muscle. This may be a reaction to the general stress of the injection and requires further investigation.

\section{Acknowledgements}

The authors are grateful to D Chourrout, M Mathieu, and JL Nicolas for their support during 
the course of this work. The authors are indebted to P Favrel and P Ganot for their technical advice and D Flament for helpful advice with the GCG package. We acknowledge J Moal, C Fabioux, JY Daniel, M Delaporte, A Le Roux, J Laisney and AH Hansen for their technical assistance. We thank all the staff of the Bouin and La Tremblade stations for providing experimental oysters and P Boudry as the supervisor of the selective breeding program. We also thank two anonymous reviewers and $\mathrm{J}$ Moal for their comments and suggestions on the manuscript. This work was supported by the MOREST national project funded by Ifremer and by the Région Basse-Normandie, Bretagne, Pays de la Loire and Poitou-Charentes and the conseil général du Calvados.

\section{References}

Bayne, C.J., Gerwick, L., Fujiki, K., Nakao, M., Yano, T., 2001. Immune-relevant (including acute phase) genes identified in the livers of rainbow trout, Oncorhynchus mykiss, by mean of suppression subtractive hybridization. Dev Comp Immunol 25, 205-217.

Boutet, I., Tanguy, A., Moraga, D., 2004. Response of the Pacific oyster Crassostrea gigas to hydrocarbon contamination under experimental conditions. Gene 329, 147-157.

Cheney, D.P., MacDonald, B.F., Elston, R.A., 2000. Summer mortality of pacific oysters, Crassostrea gigas (Thunberg): initial findings on multiple enviromental stressors in Puget Sound, Washington, 1998. J Shellfish Res 19, 353-359.

Cheng, T.C., 1996. Hemocytes: forms and functions. In: Kennedy, V.S., Newell, R.I.E., Eble, A.F. (Eds.), The Eastern Oyster Crassostrea virginica. Maryland Sea Grant, College Park, MD, USA, pp. 299-333.

Ciriolo, M.R., Palamara, A.T., Incerpi, S., Lafavia, E., Buè, M.C., De Vito, P., Garaci, E., Rotilio, G., 1997. Loss of GSH, oxidative stress, and decrease of intracellular pH as sequential steps in viral infection. J Biol Chem 272, 2700-2708. 
Dégremont, L., Boudry, P., Soletchnik, P., Bédier, E., Ropert, M., Huvet, A., Moal, J., Samain, J.F. 2003. Genetic basis of summer mortality in juvenile cupped oysters. (abstract) J Shellfish Res 22, 327.

Diatchenko, L., Lau, Y.F.C., Campbell, A.P., Chenchik, A., Moqadam, F., Huang, B., Lukyanov, S., LuKyanov, K., Gurskaya, N., Sverdlov, E.D., Siebert, P.D., 1996. Suppression subtractive hybridization: a method for generating differentially regulated or tissue-specific probes and libraries. Proc. Natl. Acad. Sci. USA 93, 6025-6030.

Diatchenko, L., Lukyanov, S., Lau, Y.F., Siebert, P.D., 1999. Suppression subtractive hybridization: a versatile method for identifying differentially expressed genes. Methods Enzymol. 303, 349-80.

Dhar, A.K., Dettori, A., Roux, M.M., Klimpel, K.R., Read, B., 2003. Identification of differentially expressed genes in shrimp (Penaeus stylirostris) infected with White spot syndrome virus by cDNA microarrays. Arch Virol 148, 2381-2396.

Fabioux, C., Huvet, A., Lelong, C., Robert, R., Pouvreau, S., Daniel, J.Y., Minguant, C., Le Pennec, M., 2004. Oyster vasa-like gene as a marker of the germline cell development in Crassostrea gigas. Biochem Biophys Res Commun 320, 592-598.

Forgac, M., 1999. Structure and properties of the vacuolar (H+)-ATPases. J Biol Chem 274, 12951-12954.

Goulletquer, P., Soletchnick, P., Le Moine, O., Razet, D., Geairon, P., Faury, N., Taillade, S., 1998. ICES Maric. Comm. 1998/CC 14.

Gueguen, Y., Cadoret, J.P., Flament, D., Barreau-Roumiguière, C., Girardot, A.L., Garnier, J., Hoareau, A., Bachère, E., Escoubas, J.M., 2003. Immune gene discovery by expressed sequence tags generated from haemocytes of the bacteria-challenge oyster, Crassostrea gigas. Gene 303, 139-145. 
Hershberger, W.K., Perdue, J.A., Beattie, J.H. 1984. Genetic selection and systematic breeding in Pacific oyster culture. Aquaculture 39, 237-245.

Hofsaess, U., Kapfhammer, J.P., 2003. Identification of numerous genes differentially expressed in rat brain during postnatal development by suppression subtractive hybridization and expression analysis of the novel rat gene rMMS2. Brain Res Mol Brain Res 113, 13-27.

Huang, X., Madan, A., 1999. CAP3: A DNA sequence assembly program. Genome Res. 9, 868-877.

Huvet, A., Dubois, S., Daniel, J.Y., Quéré, C., Prudence, M., Van Wormhoudt, A., Sellos, D., Samain, J.F., Moal, J., 2003. Tissue expression of two amylase genes in the Pacific oyster Crassostrea gigas. Effects of two different food rations. Aquaculture 228, 321-333.

Jenny, M.J., Ringwood, A.H., Lacy, E.R., Lewitus, A.J., Kempton, J.W., Gross, P.S., Warr, G.W., Chapman, R.W., 2002. Potential indicators of stress response identified by expressed sequence tag analysis of hemocytes and embryos from the American oyster, Crassostrea virginica. Mar Biotechnol 4, 81-93.

Kim, S.Y., Park, J.W., 2003. Cellular defense agaisnt singlet oxygen-induced oxidative damage by cytosolic NADP+ dependant isocitrate dehydrogenase. Free Radic Res 37, 309-316.

Lacoste, A., Jalabert, F., Malham, S., Cueff, A., Gelebart, F., Cordevant, C., Lange, M., Poulet, S., 2001. A Vibrio splendidus strain is associated with summer mortality of juvenile oysters Crassostrea gigas in the Bay of Morlaix (North Brittany, France). Dis. Aquat. Organ. 46, 139-145.

Lelong C, Mathieu M, Favrel P., 2000. Structure and expression of mGDF, a new member of the transforming growth factor-beta superfamily in the bivalve mollusc Crassostrea gigas. Eur J Biochem 267, 3986-93. 
Le Roux, F., Gay, M., Lambert, C., Waechter, M., Poubalanne, S., Chollet, B., Nicolas, J.L., Berthe, F., 2002. Comparative analysis of Vibrio splendidus-related strains isolated during Crassostrea gigas mortality events. Aquat Living Resour 15, 251-258.

Livak, K.J., Schmittgen, T.D., 2001. Analysis of relative gene expression data using real-time quantitative PCR and the 2(-Delta Delta C(T)) Method. Methods 25, 402-408.

Montagnani, C., Le Roux, F., Berthe, F., Escoubas, J.M., 2002. Cg-TIMP, an inductible tissue of metalloprotease from the Pacific oyster Crassostrea gigas with a potential role in wound healing and defense mechanisms. FEBS letters 500, 64-70.

Munoz, M., Vandenbulcke, F., Saulnier, D., Bachère, E., 2002. Expression and distribution of penaeidin antimicrobial peptides are regulated by haemocyte reactions in microbial challenged shrimp. Eur J Biochem 269, 2678-2689.

Pickering, A.D., 1992. Rainbow trout husbandry: management of the stress response. Aquaculture 100, 125-139.

Renault, T., Le Deuff, R.M., Cochennec, N., Maffart, P., 1994. Herpesviruses associated with mortalities among Pacific oyster, Crassostrea gigas, in France - Comparative study. Revue Méd Vét, 145, 735-742.

Satterlee, D.G., Johnson, W.A., 1988. Selection of Japanese quail for contrasting blood corticosterone response to immobilization. Poult. Sci. 67, 25-32.

Scotti, P.D., Dearing, S.C., Greenwood, D.R., Newcomb, R.D., 2001. Pernin: a novel selfagregating haemolymph protein from the New Zealand green-lipped mussel, Perna canaliculus (Bivalvia: Mytilidae). Comp. Biochem. Physiol. B 128, 767-779.

Shida, K., Terajima, D., Uchino, R., Ikawa, S., Ikeda, M., Asano, K., Watanabe, T., Azumi, K., Nonaka, M., Satou, Y., Satoh, N., Satake, M., Kawazoe, Y., Kasuya, A., 2003. Hemocytes of Ciona intestinalis express multiple genes involved in innate immune host defense. Biochem Biophys Res Commun 302, 207-218. 
Sorescu, G.P., Sykes, M., Weiss, D., Platt, M.O., Saha, A., Hwang, J., Boyd, N., Boo, Y.C., Vega, J.D., Taylor, W.R., Jo, H., 2003. Bone morphogenic protein 4 produced in endothelial cells by oscillatory shear stress stimulates an inflammatory response. J Biol Chem 278, 31128-35.

Tian, L., Cai, Q., Wei, H., 1998. Alterations of antioxidant enzymes and oxidative damage to macromolecules in different organs of rats during aging. Free Radic Biol Med 24, 14771484.

Tremblay, R., Myrand, B., Sevigny, J.M., Blier, P., Guderley, H., 1998. Bioenergetic and genetic parameters in relation to susceptibility of blue mussels, Mytilus edulis (L.) to summer mortality. J Exp Mar Biol Ecol 221, 27-58.

Wright, E.M., 2001. Renal Na+ glucose cotransporters. Am J Physiol Renal Physiol 280, 1018. 